\section{THU0067 ANALYSIS OF AUTOANTIGENS RECOGNISED BY AUTOANTIBODIES THAT IMMUNOPRECIPITATE HIGH MOLECULAR WEIGHT NUCLEIC ACIDS}

${ }^{1} \mathrm{M}$ Suzuki, 'M Hirakata, ${ }^{1} \mathrm{~A}$ Suwa, ${ }^{1} \mathrm{~T}$ Nojima, ${ }^{1} \mathrm{H}$ Yasuoka, ${ }^{1} \mathrm{~S}$ Satoh, ${ }^{1} \mathrm{~T}$ Fujii, ${ }^{2} \mathrm{~S}$ Inada, ${ }^{3} \mathrm{~T}$ Mimori. ${ }^{1}$ Internal Medicine, Keio University School of Medicine; ${ }^{2}$ Division of Rheumatic Disease, Tokyo Ohtsuka Metropolitan Hospital, Tokyo; ${ }^{3}$ Clinical Immunology, Kyoto University, Kyoto, Japan

\subsection{6/annrheumdis-2001.911}

Background A number of sera from patients with connective tissue diseases that immunoprecipitated high molecular weight (hmw) nucleic acid smear have been found in RNA-immunoprecipitation (IPP) assay. Most of these sera are supposed to contain autoantibodies for DNA- or mRNA- (or its precursor) related proteins. However, neither the characteristics of antigens nor the clinical significance have been well-defined.

Objectives To analyse the corresponding antigens for autoantibodies immunoprecipitating hmw-nucleic acid smear and to elucidate the clinical features associated with these autoantibodies. Methods We examined 63 sera from patients with various kinds of connective tissue diseases that immunoprecipitated $\mathrm{hmw}$ nucleic acid smear by RNA-IPP. IPP using [35S] methioninelabelled HeLa cell extracts was performed for analysis of the protein components. Immunoprecipitated nucleic acid components were treated with DNase I or RNase A to identify either DNA or RNA.

Results DNA and a heterodimer of $70 \mathrm{kDa}$ and $80 \mathrm{kDa}$ proteins (p70/p80) that was identified as the $\mathrm{Ku}$ antigen, was immunoprecipitated by 16 patient sera (4:SLE, 7: myositis overlap syndrome, 1: interstitial pneumonia (IP), 4: undiagnosed). In addition, DNA-protein complex consisting of four polypeptides $(11 \mathrm{kDa}-21 \mathrm{kDa})$ that appeared to be histone core proteins, was immunoprecipitated by 18 sera (12:SLE including one druginduced lupus, 5:MCTD/overlap syndrome, 1: autoimmune hepatitis). Eight patients sera (5:SLE, 2:RA, 1:IP) reacted with the $140 \mathrm{kDa}$ protein along with hmw-RNA smear that was supposed to be RNA helicase A. It should be noted that the remaining 37 of $63(59 \%)$ patients sera immunoprecipitated none of proteins with defined specificities, but various unidentified proteins.

Conclusion Autoantibodies to the $\mathrm{Ku}$, histone, and RNA-helicase A have been identified in patients sera with SLE and other rheumatic diseases that immunoprecipitated hmw-nucleic acid smear. However, a high percentage of these sera were found to contain novel hmw nucleic acids-related antibodies. Further analysis of these autoantibodies may provide clues for understanding the pathogenic mechanism of connective tissue diseases.

\section{Cartilage in bone biology and pathophysiology}

\section{AB0018 INTERVETEBRAL DISC HERNIATION: INVOLVEMENT OF METALLOPROTEINASES}

${ }^{1} \mathrm{~L}$ Grange, ${ }^{1} \mathrm{P}$ Gaudin, ${ }^{2} \mathrm{JJ}$ Favre, ${ }^{3} \mathrm{M}$ Peoc'h, ${ }^{1} \mathrm{R}$ Juvin, ${ }^{1} \mathrm{X}$ Phelip, ${ }^{2} \mathrm{P} \mathrm{P}$ Chirossel, ${ }^{4} \mathrm{~F}$ Morel. ${ }^{1}$ Departement of Rheumatology; ${ }^{2}$ Departement of Neurosurgery; ${ }^{3}$ Departement of Pathology, Chu, Albert Michallon, Grenoble Universitary Teaching Hospital, Grenoble, France; ${ }^{4}$ Grepi JE. EA 2019 MENRT (Groupe de Recherche Et D?Etude Du Processus Inflammatoire)

10.1136/annrheumdis-2001.912
Background Disc degeneration and physiopathology of disc herniation involves enzymatic processes mainly matrix metalloproteinases (MMPs), tissue inhibitor of metalloproteinase-1 (TIMP1) and cytokines (IL-1b, TNF-a).

Objectives This study focuses on metalloproteinases secretion and expression by disc chondrocytes isolated from herniated and not herniated zone.

Methods Eleven discs after discectomy are enzymatically digested, chondrocytes from both zones, herniated and not herniated, are cultured in alginate beads for 10 days in classical conditions. Analysis of MMP-2,-3,-7,-9,-13 and TIMP-1 by ELISA, zymography, RT-PCR and nested PCR are conducted with an immunochemical study on tissu fragments.

Results - proteic level: (ELISA, zymography):

?presence of elevated levels of MMP-3, TIMP-1 in the non herniated part

?absence of MMP-13, MMP-9, pro MMP-7 in both parts

-Transcriptional level (RT, PCR, nested PCR):

?expression of MMP-2, -3, TIMP-1 in both zones, weak expression of MMP-9 by nested PCR without difference between the two zones.

?absence or weak expression of MMP-13, -7.

Conclusion There is an heterogeneous expression of MMP -2, $3,-9$ and TIMP-1 by disc herniated and non herniated chrondocytes. The matrix metalloproteinases are probably involved early in the disc degeneration, the herniation could be the final result of matrix/cells interactions.

The secretion of TIMP-1 and MMP-3 in the herniated zone may be related discal fibrosis included into the disc cicatrization.

\section{REFERENCES}

1 Goupille P, Malcom I, Jayson V, Valat JP, Freemont AJ. Matrix metalloproteinases: the clue to Intervertébral disc degeneration? Spine 1998;23:1612-26

2 Matsui $Y$, Maeda M, Nakagami W, Iwata $H$. Theinvolvement ofmatrixmetalloproteinases in inflammation in lumbar disc herniation. Spine 1998;23:863-9

3 Crean JKG, Roberts S, Jaffray DC, Eisenstein SM, Duance VC. Matrix metalloproteinases in the human intervertebral disc. Role in disc degeneration and scoliosis. Spine 1997;22: 2877-84

4 Haro H, Crawford HC, Fingleton B, et al. Matrisian. Matrix metalloproteinase-3dependent generation of a macrophage chemoattractant in a model of herniated disc résorption. J Clin Invest. 2000;105(2):133-41

5 Poiraudeau S, Monteiro I, Anract P, Blanchard 0, Revel M, Corvol MT. Phenotic characteristic of rabbit inter vertebral disccells. Spine 1999;24:837-44

\section{AB0019 EFFECT OF EXTRACELLULAR SODIUM CONCENTRATION IN BYGLICAN AND DECORIN SYNTHESIS BY HUMAN CHONDROCYTES}

${ }^{1}$ IA Ferraz-Amaro, ${ }^{1}$ E Trujillo, ${ }^{2} \mathrm{MF}$ Arteaga, ${ }^{2} \mathrm{C}$ Cozar, ${ }^{2} \mathrm{~J}$ Avila, ${ }^{1} \mathrm{~S}$ Bustabad, ${ }^{1} \mathrm{~T}$ Gonzalez, ${ }^{2} \mathrm{P}$ Martin-Vasallo. 'Servicio de Reumatologia; ${ }^{2}$ Departamento de Biologia Y Bioquimica Molecular, Universidad de La Laguna, La Laguna, Spain

\subsection{6/annrheumdis-2001.913}

Background An altered chondrocytes phenotipic expression of biglycan and decorin is an early event in osteoarthritis (OA). Changes in extracellular matrix sodium concentration $([\mathrm{Na}+])$ occurs in OA. Previous results suggested that chondrocytes are sensitive to changes in their extracellular $[\mathrm{Na}+]$ environment and respond with variations in the matrix synthesis.

Objectives Here we have studied the influence of extracellular $[\mathrm{Na}+]$ on the metabolism of small proteoglycans, biglycan and decorin, in a human chondrocyte-like cell line, C20/A4.

Methods Extracellular deposition of biglycan and decorin was analysed in C20A4 cells cultured: 1) inmunohistochemically using specific antibodies against biglycan and decorin and 